\title{
Bibliometric Analysis of Articles on Project Management Research
}

\author{
Mehrzad Abdi Khalife1, Anna Dunay², Csaba Bálint Illés²* \\ 1 Doctoral School of Management and Business Administration, Faculty of Economics and Social Sciences, Szent István \\ University, 1 Páter Károly u., 2100 Gödöllö, Hungary \\ 2 Institute of Business Economics, Leadership and Management, Faculty of Economics and Social Sciences, Szent István \\ University, 1 Páter Károly u., 2100 Gödöllő, Hungary \\ *Corresponding author, e-mail: illes.b.csaba@gtk.szie.hu
}

Received: 10 February 2020, Accepted: 26 July 2020, Published online: 19 October 2020

\begin{abstract}
Project management, as a subsidiary of social science, is a vast and varied topic of the area of knowledge. In the past decades, many studies have compiled an immense amount of information for theoreticians and practitioners in this field. In this paper, traditional and novel methods of bibliometric analysis are introduced through a survey for analyzing the history of research in project management. This study focuses on the last four decades of publications on project management, from 1980 to 2019. In the survey, the number of publications, the countries of publication, the cooperating relations among those countries, and the top categories of publications are analyzed. The extraction of publication keywords and the investigation of knowledge seeds are also presented. In the survey, the examination of the network of top occurring keywords, keyword clustering, together with the keyword correlation matrix, were used to explore the main trends in project management. A novel indicator, called the ICCO ranking, is presented by using the degree, betweenness and cluster coefficient of the network of keywords. Using this indicator, the potential knowledge seeds in project management may be identified.
\end{abstract}

Keywords

project management, bibliometric, content analysis, keyword network, Natural Language Processing (NLP)

\section{Introduction}

The application of project management has been bound with human history since ancient times, with even our current society having been built using such projects. The Great Pyramid of Giza in Egypt (built 2570 BC) is one of the signature examples of managing large scale projects in that early age of human civilization (Uchitpe et al., 2016). In the early days of managing projects, military generals, royal family members and the elite of society acted as project managers (Garel, 2013). The methodology and concepts of modern project management were only introduced in the middle of the $20^{\text {th }}$ century (Uchitpe et al., 2016; Weaver, 2007).

The achievement or creation of defined or undefined results with a closed ended sequence of activities may be defined as a project (Project Management Institute, 2017). Project management is a vast area of research, with increasingly new concepts being added to this field (Silvius, 2017). Therefore, many different scholars should be surveyed in the literature of project management (Lehtiranta, 2014; Rodrigues-Da-Silva and Crispim, 2014; Rowlinson et al., 2014; Taroun, 2014; Taroun et al., 2011). In order to extract information from among the different studies, bibliometric analysis serves as a useful tool, as it guides researchers in gaining a better understanding of the subject trends and leads them to define any gap in the research area (Pritchard, 1969).

This study explores the research area of project management more profoundly to show the trend of the last decade and the potential of a future research area in project management. In this paper, bibliometric analysis and Natural Language Processing (NLP) tools are used to highlight the trends of the last decade. Section 2 discusses the literature used in the study. This is followed by data acquisition and methodology. The analytical results appear in Section 4, and the future is found in Section 5 on the review of this study's achievements. Section 6 is the conclusion. 


\section{Literature review}

In June 1962, the United States Department of Defense (DOD) and the National Aeronautics and Space Administration (NASA) published the PERT/Cost system document. PERT stands for program evolution and review technique and, in this document, they described what is known as the Work Breakdown Structure (WBS) (DOD-NASA, 1962). The critical path method is also one of the most well-known project-controlling techniques. Kelley and Walker (1959) developed this technique in the 1960s. WBS, PERT, and CPM were individual project management techniques until they were integrated into project management standards.

With progressive evolution, several standards were formed, for example PRINCE2, which was introduced by AXELOS, a government-owned company in the United Kingdom (OGC, 2009), and project management body of knowledge (PMBOK Guide) developed by the Project Management Institute (PMI) in the United States (Project Management Institute, 2017) are the results of this development. Nevertheless, some scholars were not satisfied with the standardized processes, and they introduced new models of managing projects (Kashiwagi, 1991; Rivera and Kashiwagi, 2016). Yet, even today, project management processes are still inefficient and ineffective processes (LePatner et al., 2007; PwC, 2009; Rivera and Kashiwagi, 2016).

The enormous amount and non-transparency of project information has led project managers to make decisions after the occurrence of a problem (Ahern et al., 2014; Elonen and Artto, 2003; Rivera and Kashiwagi, 2016). Complexity is another factor that empowers ineffective and inefficient outputs and results in a project: the project size, the number of projects led by a project manager and the nature of a project are the main contributors to project complexity (LePatner et al., 2007; PwC, 2009; Rivera and Kashiwagi, 2016), so different sets of tools and techniques are used for ensuring any project's success (Doskočil, 2016).

A part of the complexity is because project management is not just a single subject, and different scholars and different standard bodies classified the sub-knowledge areas of project management. These classifications are different and vary; as an example, Silvius, in 2017, named the sub-knowledge "schools" of project management (Silvius, 2017). The project management institute, in the project management body of knowledge guide, calls sub-knowledge "knowledge areas" (Project Management Institute, 2017), and PRINCE 2 presents the "aspects, principles and themes" in projects (OGC, 2009). These kinds of sub-classifications exist because of the variety of concepts inside project management.

Consequently, bibliometric analysis or literature review became practical survey tools to illustrate and summarize the past, identify trends and identify future potential. For classifying and analyzing the rapidly growing amount of published publications, the development of scientific bibliometric analysis is convenient and useful (Fremont, 1944; Molyneux, 1986). Billings was one of the first researchers who used bibliometric methods, to review the development of medical science (Billings, 1881). Hulme (1923) used the same method for civilization growth, and Lotka (1926) to review science in general.

With consideration of science overall, the rapid growth of the use of tools such as bibliometrics seems non-negligible, and scientists use it to review a specific subject (Ahmed and Huang, 2019; Garousi and Ruhe, 2013; Md Khudzari et al., 2018; Zhai and Ho, 2018), or specific journal (Akmal et al., 2018; Modak et al., 2019). The reviewed subject varies from cryptocurrency (Merediz-Solà and Bariviera, 2019), computer science and food security (Bouzembrak et al., 2019), medical science (Shi et al., 2019; Yang et al., 2019), micro-plastics issue and marine ecosystem (Pauna et al., 2019), to the other areas of science (Ang et al., 2019; Zou and Vu, 2019).

The diversity of project management sub-knowledge means that subjects may be reviewed from different angles. As a result of this characteristic of project management, scholars used bibliometric analysis as a scientific tool for studying various aspects of project management. Knowledge management in project management (Fernandes Pereira et al., 2015), shareholder value generation in projects (Maia and Di Serio, 2017), project governance (Oliveira Lucena et al., 2019), and risk management in foreign direct investment in infrastructure projects (Jiang et al., 2019) are samples of the application of bibliometric analysis in sub-knowledge areas of project management. De Oliveira et al. (2016) and Penha et al. (2017) used the bibliometrics method to review decision aid systems in project management and resource-constrained project scheduling, respectively. Project complexity (De Rezende et al., 2018), project sustainability (Da Rocha et al., 2013; Galvão and Alves Patah, 2017), assessment of maturity in a project (de Souza and Gomes, 2015), project success (He et al., 2019; Machado and Martens, 2015), and methodology innovation in projects (de Rezende Guerra et al., 2016) are 
other examples of bibliometrics practices in project management. Also, a different category of projects, such as mega-projects (Peng et al., 2012), construction projects (Utama et al., 2016), and software development (Lechler and Yang, 2017), as well as contingency theory in project management (Hanisch and Wald, 2012) are the other areas of application of bibliometrics in project management.

$\mathrm{Ng}$ and Chai (2015) reviewed the citation and co-citation analysis of the Project Management Journal, which is published by the Project Management Institute. While their findings are valuable, they only cover one publisher. Although the Project Management Journal is a major player in the social science field of project management, it is not a solo player, and every year, hundreds of publication releases are presented in this area. Zhang and Yang (2018) released a study based on collected data from 2007 to 2016 (one decade), in order to analyze the research status in project management using bibliometric analysis.

Indeed, the complexity and diversity of the field of project management provide a significant opportunity to analyze the context of project management with bibliometric analysis tools.

The aim of this paper is to give an in-depth bibliometric analysis to reveal the trends and the future potential of project management science.

\section{Data and methodology}

\subsection{Data}

For data acquisition, two main approaches are persuaded by scholars The first is restricted to the data and information to a specific database (Merediz-Solà and Bariviera, 2019). The second goes through all well-recognizable science databases and searches for the publications' data (Holub and Johnson, 2018). This study follows the former version. In order to avoid duplication, one wellknown database was used for this study, Web of Science (WoS), which is a valuable resource for scientific research.

For the search in the field of project management, the following combination of keywords was used:

- "project management*"

- or "management of project*"

- or "managing project*"

- or "managing the project*"

- or "projects management"

- or "project manager's tool".

The search was limited to the title of the articles to avoid irrelevant results in the search. Four decades of study were considered; the period of search started in 1980 and finished in 2019. The search was conducted in May 2020. After performing the search, all the records were scanned manually by the researchers to eliminate the irrelevant data. The final result includes 6,133 publication records, all the records saved with "full record and cited references" content in the "Tab-delimited (Mac)" format.

\subsection{Methodology}

Bibliometric network by extracting social network is a practical tool for analyzing science (Zou et al., 2018). The bibliometric method enhances researchers' systematic thinking by mapping networks (Pauna et al., 2019). The network can be shaped based on the authors, contributor's institute, geography, publisher and keywords, as well as the other fields in the research (Chen et al., 2016). For the network analysis, VOSviewer (version 1.6.13) was used (Corsi et al., 2020; Lawal et al., 2019; Y1ld1z, 2019). This software is capable of clustering, mapping networks, and visualizing the bibliometric information (van Eck and Waltman, 2010).

To review the characteristics of the research in project management, at first, the number of publications review, the linear and polynomial (order 2) regression line were used to show the trends in the last decade in project-related and project management publications. The second classification shows the top contributors in the project management field (Ahmed and Huang, 2019). The collaboration network of countries comes next, to show the collaboration clusters. A network of countries' citation is used to demonstrate how countries refer to other countries' scientific studies. After the identification of top contributors and their relations, the next step is to classify the category of research.

The keywords show the content of the article (Zhang et al., 2015). The focus of this study is on the used keywords in the publications in the last decade; the keyword shows the important knowledge area in the publications. After collecting 6,133 records from the Web of Science core collection databases, data were analyzed with VOSviewer software version 1.6.13. This software is used for bibliometric network analysis (Corsi et al., 2020; Lawal et al., 2019; Y1ld1z, 2019). The count of the keywords in the publications is used together with the keywords network for analyzing the content of the research. The top keyword correlation matrix is used to show the relations among keywords. If two keywords appear in the same article or record, the number of correlations is one, and if not, the number is zero; therefore, the number of correlations shows the number of times these two keywords appeared together in the studies. If the number of correlations is high, it shows these two keywords appear 
together in the subject several times, and if the number is low, it shows the future potential of the collaboration of those keywords. For the top occurring keywords, the low correlation number in the matrix shows the future possibility of a combination of top occurring keywords.

For in-depth analysis in the keywords, the ICCO rank is used. ICCO stands for indicator, cluster coefficient and occurrences of keywords; the ranking method uses the I-C indicator (Wang and Chai, 2018). The I-C indicator is based on the keyword network and graph theory. This indicator has two parts, I and C. Each keyword is one node, and the number of correlations is the edge of the network. The I indicator is the node betweenness divided by node degree. The node betweenness and node degree extract from the co-word network structure. In the co-word network structure, the indicators such as degree, betweenness, closeness and modularity are measured (GonzálezAlcaide et al., 2015; Jiandong, 2009). The degree shows the direct connection situation in the co-word network structure, and betweenness represents the capability of bringing communities (Kumar and Markscheffel, 2016). In the keyword co-word network degree, the connection of the specific keyword is represented with the other keywords in the network: more degrees show more connectivity, and it is a positive event. The higher betweenness means the essential role for that keyword in the network. Both of them have a positive correlation with the number of occurrences, so they are not reliable individual measures for the future potential of the subject.

For connection of degree and betweenness, the I indicator was introduced by Wang and Chai (2018) to describe a node's average information load in a co-word network structure, which is betweenness divided by degree. In this case, the betweenness of the keyword was normalized by the degree of the same keyword. The higher I indicator means more potential for future growth. The I indicator can identify the knowledge seed in the network (Wang and Chai, 2018). However, individually it does not represent the full potential.

The clustering coefficient is the $\mathrm{C}$ indicator, which is a prone clustering degree of nodes in the co-word network (Zhu et al., 2013). Indicator C shows the situation of a node among its neighborhood nodes, and a higher $\mathrm{C}$ value has a negative impact on the birth of new areas of knowledge or information transmission (Zamzami and Schiffauerova, 2017).

Wang and Chai combined the I and $\mathrm{C}$ indicators to generate new measures to find the potential knowledge area (Wang and Chai, 2018). I indicator identifies the potential knowledge seed, and the $\mathrm{C}$ indicator shows the surrounding environment. This indicator, in short, is named I-C indicator.

In this study, the two indicators (I and C) are used for measuring the potential of future expansion. The problem is that the method does not differentiate the high number and a low number of occurrences in the keywords, and it measures all of them together. The novelty of this study is that it adds a twist to solve this problem: after weighing the I and $\mathrm{C}$ indicators, both indicators are ranked for each keyword identification and then the sum of ranks plus the occurrence of the keyword are added together to shape a new ranking measure. Finally, the result is ranked from a lower value to a high value. Here, the new measure is called I indicator, cluster coefficient and occurrence ranking (abbreviated as ICCO rank). Then, the ranking of ICCO rank shows the future potential of growth in the study, with a higher ranking (means 1) that has a higher potential for growth. The collected data were preprocessed by Bibexcel software and the network analyzed by Gephi software.

\section{Result}

\subsection{Number of publications}

Fig. 1 illustrates the number of publications in the project management title in the Web of Science from 1980 to 2019. In 1980, there were just seventeen publications, almost one and a half publications for each month, and the search results ended up with 249 records for publication in 2019.

Table 1 shows the number of publications in the previous decade, and the numbers are calculated by the percentage of publications plus the growth rate of the publications. The publications in the last decade are more than the total sum of the preceding three decades of publications.

Nevertheless, the growth rate is not steady. At the beginning of the decade, it has a negative slope and then for four years, it rapidly goes up. Afterwards, it declined continually until 2019.

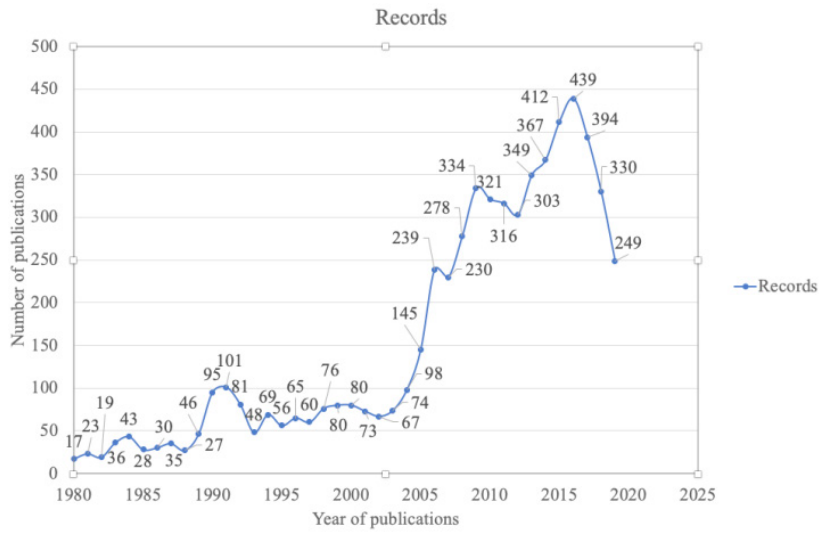

Fig. 1 Number of publications in the last four decades 
Table 1 Number of publications in the last decade

\begin{tabular}{lccc}
\hline Year & $\begin{array}{c}\text { Number of } \\
\text { records }\end{array}$ & $\begin{array}{r}\text { Percentage of total } \\
\text { publication }\end{array}$ & $\begin{array}{c}\text { Growth from the } \\
\text { former year }\end{array}$ \\
\hline 2019 & 249 & $4.06 \%$ & $-24.55 \%$ \\
2018 & 330 & $5.38 \%$ & $-16.24 \%$ \\
2017 & 394 & $6.42 \%$ & $-10.25 \%$ \\
2016 & 439 & $7.16 \%$ & $6.55 \%$ \\
2015 & 412 & $6.72 \%$ & $12.26 \%$ \\
2014 & 367 & $5.98 \%$ & $5.16 \%$ \\
2013 & 349 & $5.69 \%$ & $15.18 \%$ \\
2012 & 303 & $4.94 \%$ & $-4.11 \%$ \\
2011 & 316 & $5.15 \%$ & $-1.56 \%$ \\
2010 & 321 & $5.23 \%$ & $-3.89 \%$ \\
Sum & 3480 & $56.74 \%$ & \\
\hline
\end{tabular}

To see the trend line of the number of publications, regression methodology was used. The best-fitted line is the fifth-order polynomial line, the equation and the $R^{2}$ of this line is in Fig. 2. For the prediction of the number of publications in 2020, these are based on this fitted line, and the number of publications decline. However, with close observation, another trend is visible. There are three major local peaks, the first one is in 1991 with 101 publications, the second is in 2009 with 334 , and the third one is in 2016 with 439 publications. These peaks are followed by a rapid decline in the years thereafter. For the first peak, it took thirteen years to come back to the level of 1991 by 98 publications in 2004; and for 2009, three consecutive years with negative growth are observed. This could be the same scenario for the 2016 peak, and maybe 2020 is time the number of publications rebounds back and grows.

\subsection{Top contributors' countries}

The United States, with $18.88 \%$ of publications, is followed by China, with $12.93 \%$ of publications. These two countries publish approximately one-third of contributions

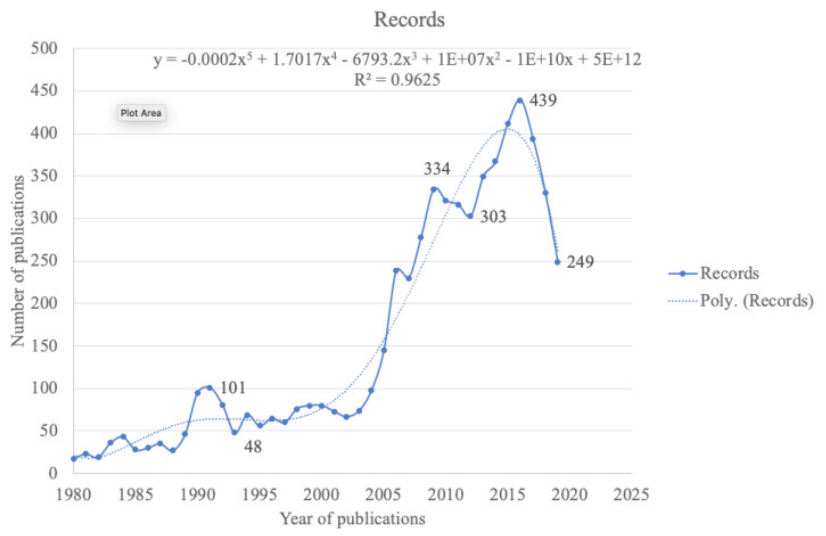

Fig. 2 Regression line for the number of publications in the subject area project management. England, Brazil and Australia are in third to fifth place in this regard. Fig. 3 shows the mosaic plot of the top twenty contributors in the project management topic. For more in-depth analysis, Fig. 4 introduces the network of co-authorship of different countries. The network shapes six clusters; the first cluster contains the four major European Union countries Germany, France, Italy and Spain plus Russia, Poland and Romania. The second cooperation cluster is between England, South Africa, Portugal and Brazil. The third cluster contains the contributor's leader, the United States and China with Taiwan. The fourth to sixth clusters are double-member clusters, AustraliaCzech Republic, Canada-Sweden, and Japan-Malaysia are the fourth to sixth clusters, respectively.

Fig. 5 demonstrates the citation aspects of the different countries' correlation in the publication. The citation network of these 20 top countries shapes three clusters; these three citation clusters show how the countries citing the other countries work and how they use each other's publications.

\subsection{Category of research}

Fig. 6 shows the 10 top categories of research in project management. It illustrates how project management and project topic is a vast subject, and it can cover all the research fields. According to research categories, management comes in first place, followed by business, operation

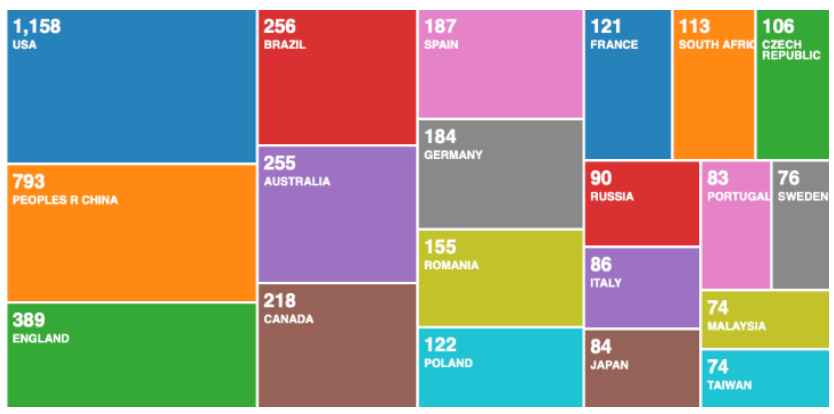

Fig. 3 Mosaic plot 1of Top 20 countries

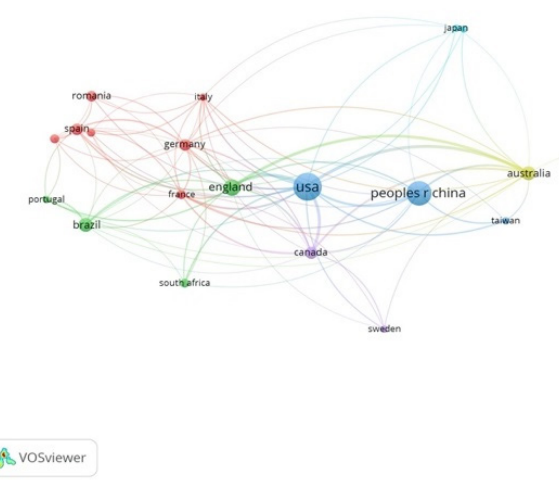

Fig. 4 Top 20 countries authorship network 


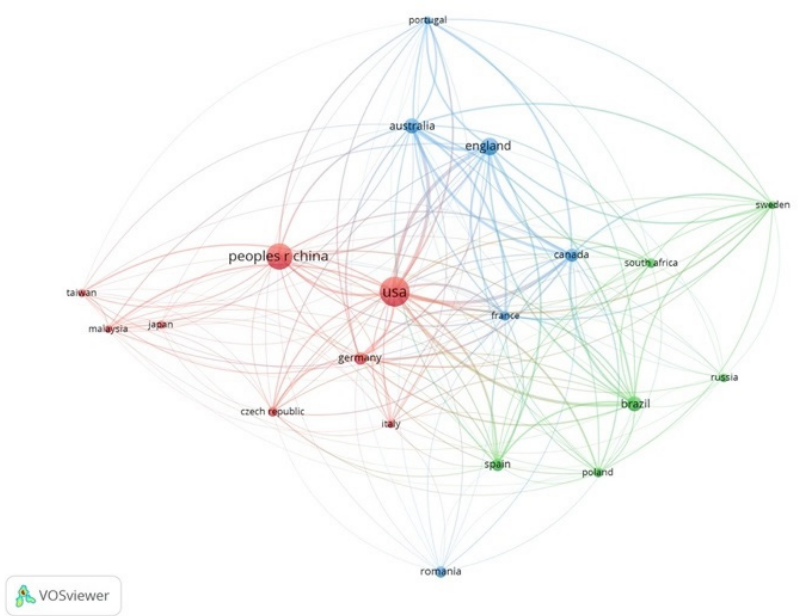

Fig. 5 Top 20 countries citation network

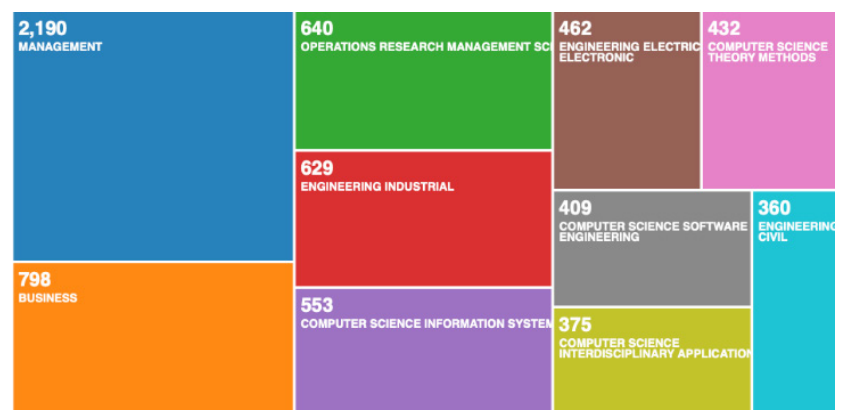

Fig. 6 Top 10 categories of research

research management science, engineering industrial and computer science and information system.

\subsection{Keyword}

Zhang et al. (2015) compared authors' keywords and KeyWords Plus. The authors' keywords are those which were given by the publications' authors and KeyWords Plus are added to the article by the publishing organization. The effectiveness of KeyWords Plus is the same as author keywords, but the use of KeyWords Plus for showing the article content is less comprehensive than authors' keywords.

As the cited research of Zhang et al. (2015) is in the medical field, they claimed it might be different in other scientific areas. We therefore decided to use the combination of both keyword types, authors' keywords as well as KeyWords Plus.

As Zhang and his team mentioned in their study, the keywords are representative of the article content, and they show the research area (Zhang et al., 2015).

VOSviewer is a powerful software using Natural Language Processing (NLP) to identify the top occurring keywords and to visualize the relations between these keywords. For this part of the analysis, the search keywords were eliminated from the final results because those keywords are the main concepts, and the present study tries to find the sub-discussion of the topic. For this particular study, the recorded results in the Web of Science did not $\log$ keywords before 1990, and all the records are without keywords; therefore, the study is limited to the records from 1990 to 2019. The period was divided into three decades for the initial analysis. In Fig. 7, the top 30 keywords network and the clusters are demonstrated; Fig. 7 is followed by a correlation matrix in Table 2.

There are five clusters in the keywords network between 1990 to 1999. The details of this cluster are displayed in Appendix A. Appendix A shows the three periods clustering plus the occurrences of the top 30 keywords.

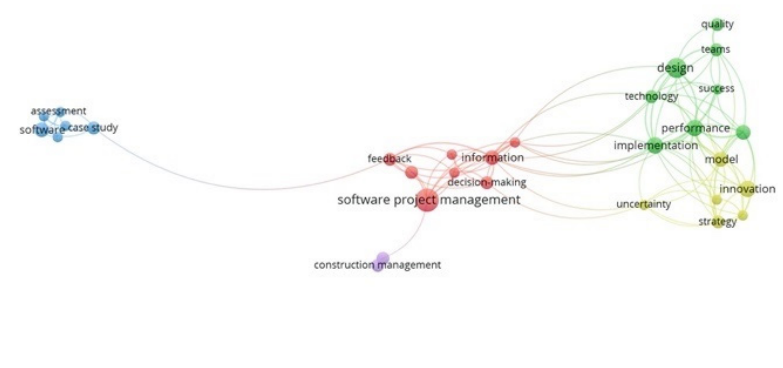

is vosviewer

Fig. 7 Top 30 keywords network from 1990 to 1999

Table 2 Correlation matrix of top occurred keywords from 1990 to 1999

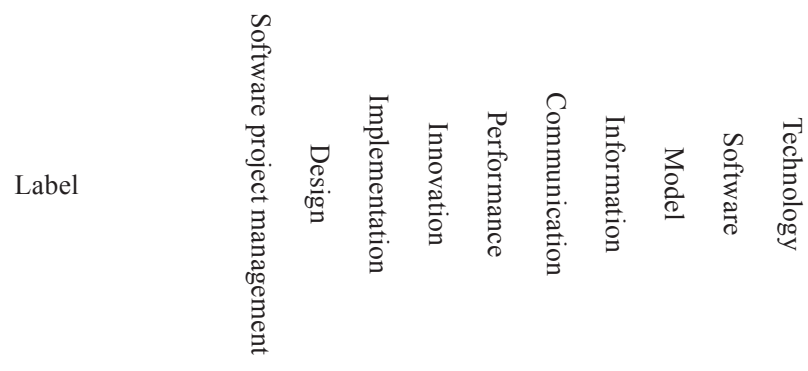

\begin{tabular}{llllllllll}
\hline $\begin{array}{l}\text { Software project } \\
\text { management }\end{array}$ & - & & & & & & & \\
Design & 0 & - & & & & & & & \\
Implementation & 1 & 2 & - & & & & & & \\
Innovation & 0 & 0 & 1 & - & & & & & \\
Performance & 0 & 2 & 1 & 2 & - & & & & \\
Communication & 0 & 1 & 1 & 2 & 3 & - & & & \\
Information & 2 & 1 & 1 & 0 & 1 & 0 & - & & \\
Model & 0 & 2 & 1 & 2 & 2 & 2 & 0 & - & \\
Software & 0 & 0 & 0 & 0 & 0 & 0 & 0 & 0 & - \\
Technology & 0 & 2 & 2 & 0 & 2 & 1 & 1 & 1 & 0 \\
\hline
\end{tabular}


This matrix shows the potential for future work in the last decade of the previous century.

The next decade is the first of the third millennium, from 2000 to 2009 . Fig. 8 shows the top 30 keywords network, and Table 3 is the correlation matrix of keywords.

With a visual comparison of Fig. 7 and Fig. 8, it is obvious that the keywords are more linked with each other, and they are also more connected. Clustering information and the occurrences of Fig. 8 is given in Appendix A.

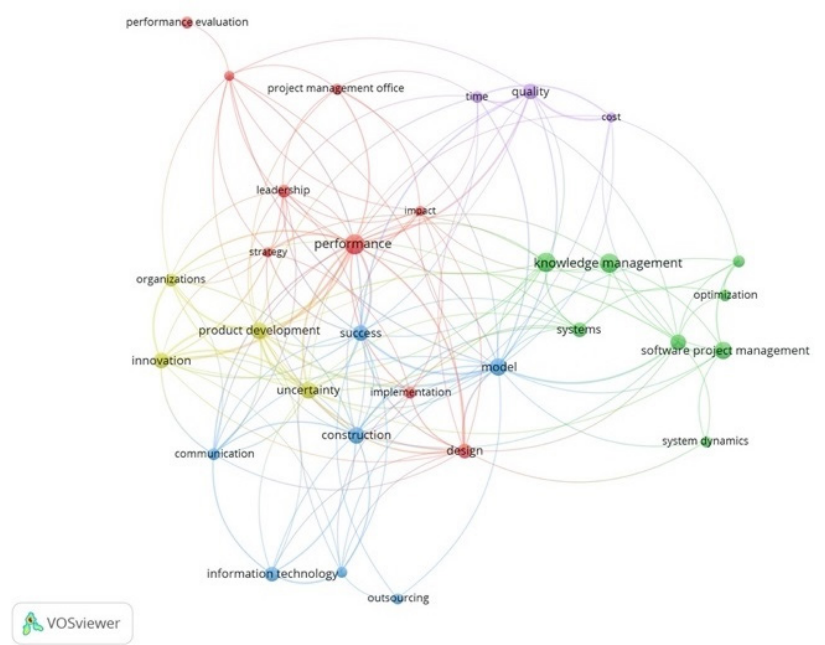

Fig. 8 Top 30 keywords network for 2000 to 2009

Table 3 Correlation matrix of top occurred keywords from 2000 to 2009

\begin{tabular}{|c|c|c|c|c|c|c|c|c|c|c|}
\hline Label & 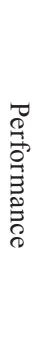 & 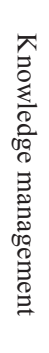 & 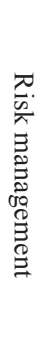 & $\begin{array}{l}3 \\
\frac{3}{0} \\
\stackrel{2}{0}\end{array}$ & 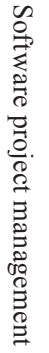 & 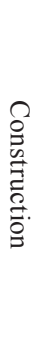 & 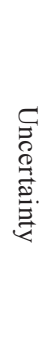 & 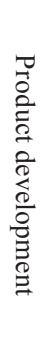 & 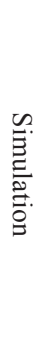 & $\begin{array}{l}\mathscr{D} \\
\tilde{D} \\
\tilde{D} \\
\tilde{D} \\
\infty\end{array}$ \\
\hline Performance & - & & & & & & & & & \\
\hline $\begin{array}{l}\text { Knowledge } \\
\text { management }\end{array}$ & 1 & - & & & & & & & & \\
\hline Risk management & 1 & 1 & - & & & & & & & \\
\hline Model & 2 & 0 & 1 & - & & & & & & \\
\hline $\begin{array}{l}\text { Software Project } \\
\text { management }\end{array}$ & 0 & 1 & 1 & 1 & - & & & & & \\
\hline Construction & 0 & 0 & 0 & 2 & 0 & - & & & & \\
\hline Uncertainty & 4 & 0 & 2 & 2 & 1 & 0 & - & & & \\
\hline $\begin{array}{l}\text { Product } \\
\text { development }\end{array}$ & 4 & 0 & 0 & 6 & 0 & 1 & 6 & - & & \\
\hline Simulation & 0 & 0 & 1 & 4 & 4 & 1 & 0 & 2 & - & \\
\hline Success & 5 & 0 & 1 & 5 & 0 & 1 & 3 & 2 & 0 & - \\
\hline
\end{tabular}

The last decade started in 2010 and finished in 2019, and Fig. 9 demonstrates the visualization of the top 30 keywords network in this period. The number of clusters are reduced to four clusters, and the connection lines increased dramatically. The clusters and occurrences of each keyword are in Appendix A.

The correlation matrix of the top ten keywords is demonstrated in Table 4. Table 2 and Table 3 show the history of the keywords in the last decade of the twentieth century and the first decade of the twenty-first century respectively. Based on these two tables, it was obvious that there was a high potential for new studies. However, the last decade's top ten correlation matrix does not have any zeros, and it shows all the keywords came together in publications. The minimum correlation number in the correlation matrix is between construction and innovation.

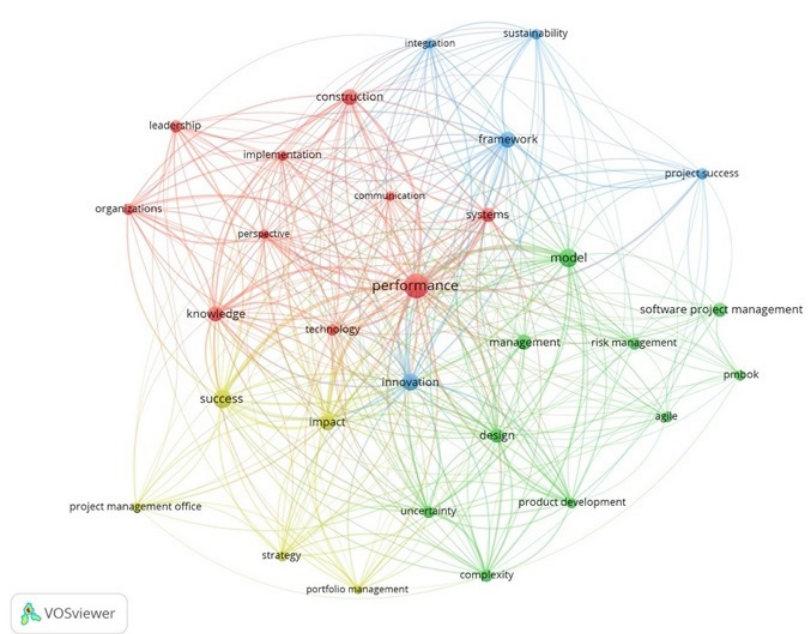

Fig. 9 Top 30 keywords network for 2010 to 2019

Table 4 Correlation matrix of top occurred keywords from 2010 to 2019

\begin{tabular}{|c|c|c|c|c|c|c|c|c|c|c|}
\hline Label & 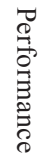 & $\begin{array}{l}3 \\
0 \\
0 \\
0\end{array}$ & $\begin{array}{l}n \\
\tilde{D} \\
\delta \\
\varnothing \\
\infty\end{array}$ & 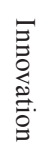 & 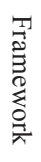 & 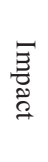 & 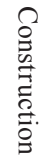 & 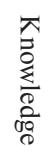 & 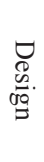 & $\begin{array}{l}\underset{1}{\infty} \\
\stackrel{\infty}{\overrightarrow{0}} \\
\stackrel{0}{3}\end{array}$ \\
\hline Performance & - & & & & & & & & & \\
\hline Model & 39 & - & & & & & & & & \\
\hline Success & 42 & 15 & - & & & & & & & \\
\hline Innovation & 19 & 6 & 17 & - & & & & & & \\
\hline Framework & 21 & 9 & 12 & 14 & - & & & & & \\
\hline Impact & 37 & 12 & 22 & 12 & 9 & - & & & & \\
\hline Construction & 21 & 10 & 5 & 3 & 8 & 8 & - & & & \\
\hline Knowledge & 20 & 8 & 10 & 8 & 5 & 12 & 10 & - & & \\
\hline Design & 20 & 6 & 10 & 7 & 6 & 10 & 7 & 4 & - & \\
\hline Systems & 18 & 9 & 4 & 9 & 7 & 7 & 9 & 4 & 4 & - \\
\hline
\end{tabular}


The subsequent analysis of the keywords is a measurement of ICCO rank. To demonstrate the algorithm, the year 2016 was selected because it has a higher number of publications. The records of that year's analysis are shown in Appendix B. Top 10 occurrences, degree, betweenness, I indicator and clustering coefficient are given in Appendix B. The appendix table shows that the result of each indicator is different from the occurrences. Table 5 shows the ICCO value and the ICCO rank result for the given year. In Table 5, the number of occurrences, the ranking of degree, ranking of betweenness and ranking of I indicator are demonstrated as well as ICCO results and the ICCO rank, which is from one to ten in this table.

The same process was repeated for the second half of the last decade to see the potential keywords, and the results come in Tables 6 and 7. Table 5, Table 6 and Table 7 demonstrate the high potential keywords as knowledge seed for project management in the last half-decade.

The list is dynamic, and it is different from one year to another. The agility, communication, construction and software project management are top potential keywords for the last two years.

\section{Discussion}

Project and project management concepts were always linked to civilized humanity from an early age, but it became an independent knowledge and science in the last century. The number of publications shows the growth in the field, even though this growth is not constant and

Table 5 ICCO ranking for 2016

\begin{tabular}{|c|c|c|c|c|c|c|}
\hline Keyword & 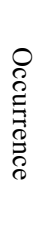 & 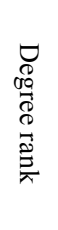 & 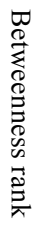 & 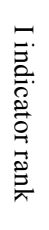 & $\tilde{\Omega}$ & $\begin{array}{l}\bar{\Omega} \\
\widehat{O} \\
\vec{\Omega} \\
\vec{N}\end{array}$ \\
\hline $\begin{array}{l}\text { Construction project } \\
\text { management }\end{array}$ & 5 & 36 & 10 & 6 & 26 & 1 \\
\hline Simulation & 4 & 23 & 5 & 3 & 32 & 2 \\
\hline Leadership & 6 & 7 & 2 & 8 & 34 & 3 \\
\hline $\begin{array}{l}\text { Project management maturity } \\
\text { models }\end{array}$ & 3 & 112 & 22 & 2 & 36 & 4 \\
\hline Global software development & 5 & 30 & 14 & 12 & 43 & 5 \\
\hline Construction project & 5 & 36 & 17 & 18 & 45 & 6 \\
\hline Agile & 7 & 7 & 3 & 22 & 47 & 7 \\
\hline Human resources & 3 & 75 & 16 & 1 & 52 & 8 \\
\hline Earned value management & 3 & 30 & 12 & 11 & 54 & 9 \\
\hline Innovation & 6 & 15 & 15 & 35 & 58 & 10 \\
\hline
\end{tabular}

Table 6 ICCO ranking for 2015 and 2017

\begin{tabular}{|c|c|c|c|c|}
\hline & 2015 & & 2017 & \\
\hline $\begin{array}{l}\text { ICCO } \\
\text { Rank }\end{array}$ & 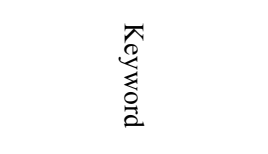 & $\begin{array}{l}0 \\
\varnothing \\
\varrho \\
\vdots \\
0 \\
0 \\
0 \\
\varnothing\end{array}$ & $\begin{array}{l}\underset{Q}{\mathbb{Z}} \\
\stackrel{z}{z} \\
0 \\
0\end{array}$ & 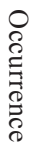 \\
\hline 1 & PMBOK & 6 & Risk analysis & 4 \\
\hline 2 & $\begin{array}{c}\text { Software project } \\
\text { management }\end{array}$ & 9 & Barriers & 4 \\
\hline 3 & Software engineering & 5 & $\begin{array}{c}\text { Project management } \\
\text { system }\end{array}$ & 3 \\
\hline 4 & Teamwork & 3 & Simulation & 6 \\
\hline 5 & Leadership & 4 & SCRUM & 5 \\
\hline 6 & $\begin{array}{c}\text { Project management } \\
\text { maturity }\end{array}$ & 4 & $\begin{array}{l}\text { Engineering } \\
\text { management }\end{array}$ & 3 \\
\hline 7 & Project success & 5 & $\begin{array}{c}\text { Sustainable } \\
\text { development }\end{array}$ & 3 \\
\hline 8 & $\begin{array}{c}\text { Project management } \\
\text { processes }\end{array}$ & 3 & $\begin{array}{l}\text { Artificial neural } \\
\text { networks }\end{array}$ & 2 \\
\hline 9 & Agile & 10 & $\begin{array}{c}\text { Construction project } \\
\text { management }\end{array}$ & 3 \\
\hline 10 & Engineering & 5 & $\begin{array}{l}\text { Knowledge } \\
\text { management }\end{array}$ & 4 \\
\hline
\end{tabular}

Table 7 ICCO ranking for 2018 and 2019

\begin{tabular}{|c|c|c|c|c|}
\hline & 2018 & & 2019 & \\
\hline $\begin{array}{l}\text { ICCO } \\
\text { Rank }\end{array}$ & 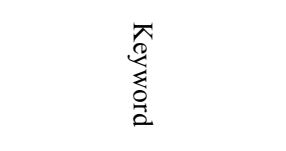 & 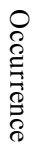 & 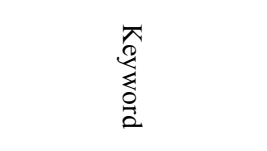 & 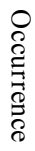 \\
\hline 1 & IT project management & 5 & Project scheduling & 4 \\
\hline 2 & Risk analysis & 3 & $\begin{array}{c}\text { Software project } \\
\text { management }\end{array}$ & 7 \\
\hline 3 & PMBOK & 5 & Agile & 5 \\
\hline 4 & Fuzzy logic & 3 & Construction industry & 5 \\
\hline 5 & IT project & 3 & $\begin{array}{c}\text { Systematic literature } \\
\text { review }\end{array}$ & 3 \\
\hline 6 & Project success & 6 & Performance & 4 \\
\hline 7 & Case study & 4 & $\begin{array}{c}\text { Project management } \\
\text { maturity }\end{array}$ & 4 \\
\hline 8 & Communication & 5 & $\begin{array}{c}\text { Project management } \\
\text { office }\end{array}$ & 4 \\
\hline 9 & $\begin{array}{c}\text { Construction project } \\
\text { management }\end{array}$ & 3 & $\begin{array}{c}\text { Project management } \\
\text { system }\end{array}$ & 4 \\
\hline 10 & Agile & 9 & Communication & 2 \\
\hline
\end{tabular}

not rapid. It seems that in the next few years, the number of publications will grow, and it may surpass the 2016 number of publications in the subject of project management in a few years. 
Two top players in the field of social sciences are the United States of America and the People's Republic of China. One-third of publications are contributed by these two countries, and there are a high number of cooperation and citation links between them. Although England, Australia and Canada are Commonwealth countries and all of them contributed greatly in publishing on project management, they are not in the same cluster of collaboration, and each of them work with a different group of countries. On the contrary, in relation to citation, these countries cited each other's works frequently, and they are in the same cluster. The subject category shows the diversification of the subject in project management.

Keyword analysis is a powerful tool for content analysis, and it may be used for predicting the potential of future growth and direction of knowledge (Wang and Chai, 2018). Keywords network, together with the keywords correlation matrix, describe the history of the top occurring keywords in project management. The correlation matrix is a useful tool for scholars to understand the relations of top keywords and may be a guide for scholars. Keywords of the first analyzed decade showed that most of the subjects in that period were developed individually, and there was less collaboration between disciplines. The level of collaboration among the keywords increased progressively and, in the last decade, it is obvious that there is a high level of correlation between the top occurred keywords.

Based on the results of last decade, the top keyword correlation matrix of construction-innovation has a high chance of being a seed of knowledge development, even though both keywords came together three times. The second potential can be success-systems, knowledge-design, design-systems, and design-knowledge. The correlation matrix is a robust tool for identifying the potential knowledge seed, but it has week points. First, it analyses the top occurring topic in the field of study, which is already the focus of research for that field. Second, it is only a one-dimension design making tool.

To add more accuracy for finding the knowledge seed, the ICCO ranking could be used. ICCO ranking looks into the mid occurring keywords, and it makes decisions based on a combination of keyword occurrences, degree, betweenness and cluster coefficient of the keyword network. The project scheduling, communication, agility, and performance, along with project management software, maturity, office and system have a high potential for being the future knowledge seed of project management. Knowledge seeds are guidelines for scholars and practitioners for choosing the next research and work subject.

\section{Conclusion}

Project management is not a new concept in research, and the development of this field of science has been significant from the start. Also, this knowledge area has a different variety of sub-sciences and sub-knowledge. Moreover, this science is used in various fields of science and in practice. By searching project management keywords, researchers may face a vast open area, and it is tough to navigate in this field. Therefore, this study has tried to enlighten the scholars and practitioners in this field of science and give or suggest the future development clues.

In this regard, this study reviewed the relevant literature from 1980 to 2019 and the data was collected in May 2020. The data were divided into four intervals and each range consisted of information of a decade: two decades represented the end of the last century and two decades presented the start of the twenty-first century. The Web of Science core collection database was selected for collecting data and 6,133 records gathered. The study started by analyzing the number of publications, which overall shows growth. There were times with rapid growth, followed by a few years of stagnation in the number of publications in this field. It represents that the topic is not a new one, and has reached its maturity period of time.

The United States and China are ranked first and second according to contributor country; these two countries contributed one-third of all publications. The four top-ranking areas of research in project management are "management", "business", "operation research", and "industrial engineering"; and these areas are responsible for more than half of the published research studies.

Keyword analysis was used for analyzing the records. First, the top occurring keywords were introduced, and their network shaped further analysis. The keyword clustering and the keywords correlation matrix were presented to find the future potential of knowledge in project management, and VOSviewer was used for extraction of the top keywords and the keyword network.

Based on the correlation matrix, construction-innovation, success-systems, knowledge-design, design-systems, and design-knowledge are the key combinations that have high potential for growth and development in the subject of project management.

For in-depth analysis of the keywords and for finding the knowledge seed for future development and studies, a new ranking system was introduced. This ranking system is named ICCO. The ICCO ranking stands for I indicator, clustering coefficient and occurrences because the method uses these indicators of the keywords' network 
for analysis the potential. The I indicator is the betweenness of the nodes normalized by degree of that individual node, which here nodes are representative of keywords.

The ICCO ranking was implemented for the last five years of keywords and the knowledge seed of each year identified. According to the results, Project scheduling, PM software, Agile, construction, Performance, PM maturity, PM office (PMO), PM system and communication are the top topics as knowledge seed in project management. The Systematic Literature Review (SLR) is in fifth place and has a high level of potential for future growth. The growth of the application of the literature review is growing due to the increase in the number of publications;

\section{References}

Ahern, T., Leavy, B., Byrne, P. J. (2014) "Complex project management as complex problem solving: A distributed knowledge management perspective", International Journal of Project Management, 32(8), pp. 1371-1381.

https://doi.org/10.1016/j.ijproman.2013.06.007

Ahmed, S., Huang, B. (2019) "Control engineering practice in 25 years: A bibliometric overview", Control Engineering Practice, 88, pp. 16-20.

https://doi.org/10.1016/j.conengprac.2019.04.004

Akmal, A., Podgorodnichenko, N., Greatbanks, R., Everett, A. M. (2018) "Bibliometric analysis of production planning and control (1990-2016)", Production Planning \& Control: The Management of Operations, 29(4), pp. 333-351.

https://doi.org/10.1080/09537287.2018.1429030

Ang, W. L., Wahab Mohammad, A., Johnson, D., Hilal, N. (2019) "Forward osmosis research trends in desalination and wastewater treatment: A review of research trends over the past decade", Journal of Water Process Engineering, 31, Article Number: 100886. https://doi.org/10.1016/j.jwpe.2019.100886

Billings, J. S. (1881) "An Address on our Medical Literatur", The British Medical Journal, 2, pp. 262-268. https://doi.org/10.1136/bmj.2.1076.262

Bouzembrak, Y., Klüche, M., Gavai, A., Marvin, H. J. P. (2019) "Internet of Things in food safety: Literature review and a bibliometric analysis", Trends in Food Science \& Technology, 94, pp. 54-64. https://doi.org/10.1016/j.tifs.2019.11.002

Chen, D., Liu, Z., Luo, Z., Webber, M., Chen, J. (2016) "Bibliometric and visualized analysis of emergy research", Ecological Engineering, 90, pp. 285-293.

https://doi.org/10.1016/j.ecoleng.2016.01.026

Corsi, A., Pagani, R. N., Kovaleski, J. L., Luiz Da Silva, V. (2020) "Technology transfer for sustainable development: Social impacts depicted and some other answers to a few questions", Journal of Cleaner Production, Article Number: 118522. https://doi.org/10.1016/j.jclepro.2019.118522 therefore, SLR is a useful tool for classification and clustering of studies in a field of science.

Gephi software was used for network analysis and measuring the network indicators. The raw information was preprocessed using Bibexcel software.

Project management is a vast area of knowledge, and it is shaped by different combinations of keywords. This study tried to classify the trends and the studies in the project management and to introduce the high potential agenda in the project research area. Along with the introduction of the new agenda, a novel indicator was also introduced to measure and rank the potential of future research in project management.

Da Rocha, A. C., Maffini Gomes, C., Marques Kneipp, J., Rossetto Camargo, C. (2013) "Gestão de Projetos e Sustentabilidade: Um Estudo Bibliométrico da Produção Científica na Base Web of Science" (Project Management and Sustainability: A Bibliometric Study of Scientific Production in Basis Web of Science), Revista de Gestão e Projetos, 4(3), pp. 73-97. (in Portuguese) https://doi.org/10.5585/gep.v4i3.200

de Oliveira, L. V., de Oliveira Lacerda, R. T., Goncalves Silveira Fiates, G., Ensslin, S. R. (2016) "Avaliação de Desempenho e Gerenciamento de Projetos: Uma Análise Bibliométrica" (Decision Aid in Project Management: A Bibliometric Analysis), Revista de Gestão e Projetos, 7(1), pp. 95-113. (in Portuguese) https://doi.org/10.5585/gep.v7i1.329

de Rezende Guerra, S., Bilessimo, S. M. S., de Sá Freire, P., Gruber, V., da Silva, S. M. (2016) "Metodologias de Gestão de Projetos de Inovação: Uma Análise Bibliométrica sobre a Produção Científica Relacionada" (Methodologies Innovation Project Management: A Bibliometric Analysis of Scientific Production Related), Revista Administração Em Diálogo, 18(3), pp. 119-138. (in Portuguese) https://doi.org/10.20946/rad.v18i3.25287

De Rezende, L. B., Blackwell, P., Pessanha Gonçalves, M. D. (2018) "Research Focuses, Trends, and Major Findings on Project Complexity: A Bibliometric Network Analysis of 50 Years of Project Complexity Research", Project Management Journal, 49(1), pp. 42-56. https://doi.org/10.1177/875697281804900104

de Souza, T. F., Gomes, C. F. S. (2015) "Assessment of Maturity in Project Management: A Bibliometric Study of Main Models", Procedia Computer Science, 55, pp. 92-101. https://doi.org/10.1016/j.procs.2015.07.012

Department of Defense, National Aeronautics and Space Administration (DOD-NASA) (1962) "DOD and NASA guide: PERT COST systems design", United States Department of Defense; United States National Aeronautics and Space Administration, Washington, DC, USA. 
Doskočil, R. (2016) "The Level of Use of Project Management Methods, Techniques and Tools and Their Impact on Project Success Selected Region of Czech Republic", Periodica Polytechnica Social and Management Sciences, 24(1), pp. 14-24. https://doi.org/10.3311/PPso.8236

Elonen, S., Artto, K. A. (2003) "Problems in managing internal development projects in multi-project environments", International Journal of Project Management, 21(6), pp. 395-402. https://doi.org/10.1016/S0263-7863(02)00097-2

Fernandes Pereira, T., de Carvalho Miranda, R., Barra Montevechi, J. A. (2015) "Gestão do conhecimento em projetos de simulação: um estudo bibliométrico" (Knowledge management in simulation projects: a bibliometric study), Perspectivas em Ciência da Informação, 20(1), pp. 138-155. (in Portuguese) https://doi.org/10.1590/1981-5344/2038

Fremont, R. (1944) "The Scholar and the Future of the Research Library: A Problem and its Solution", Hadham Press, New York, NY, USA.

Galvão, G. D. A., Alves Patah, L. (2017) "Gestão de Projetos Sustentáveis e Inovadores: Um Estudo Bibliométrico" (Management of Sustainable and Innovative Projects: A Bibliometric Study), Revista de Gestão e Projetos, 8(3), pp. 29-49. (in Portuguese) https://doi.org/10.5585/gep.v8i3.553

Garel, G. (2013) "A history of project management models: From pre-models to the standard models", International Journal of Project Management, 31(5), pp. 663-669. https://doi.org/10.1016/j.ijproman.2012.12.011

Garousi, V., Ruhe, G. (2013) "A Bibliometric/Geographic Assessment of 40 Years of Software Engineering Research (1969-2009)", International Journal of Software Engineering and Knowledge Engineering, 23(09), pp. 1343-1366. https://doi.org/10.1142/S0218194013500423

González-Alcaide, G., Park, J., Huamaní, C., Belinchón, I., Ramos, J. M. (2015) "Evolution of Cooperation Patterns in Psoriasis Research: Co-Authorship Network Analysis of Papers in Medline (19422013)", Plos One, 10(12), Article Number: e0144837. https://doi.org/10.1371/journal.pone.0144837

Hanisch, B., Wald, A. (2012) "A Bibliometric View on the Use of Contingency Theory in Project Management Research", Project Management Journal, 43(3), pp. 4-23. https://doi.org/10.1002/pmj.21267

He, Q., Wang, T., Chan, A. P. C., Li, H., Chen, Y. (2019) "Identifying the gaps in project success research: A mixed bibliographic and bibliometric analysis", Engineering Construction and Architectural Management, 26(8), pp. 1553-1573.

https://doi.org/10.1108/ecam-04-2018-0181

Holub, M., Johnson, J. (2018) "Bitcoin research across disciplines", The Information Society: An International Journal, 34(2), pp. $114-126$. https://doi.org/10.1080/01972243.2017.1414094

Hulme, E. W. (1923) "Statistical Bibliography in Relation to the Growth of Modern Civilization: Two Lectures delivered in the University of Camibridge in May 1922", Nature, 122(2816), pp. 585-586. https://doi.org/10.1038/112585a0

Jiandong, W. (2009) "Domestic Information Services Research Concept Network Analysis Based on Complex Network Method", Data Analysis and Knowledge Discovery, 10, pp. 56-61. (in Chinese) https://doi.org/10.11925/infotech.1003-3513.2009.10.10
Jiang, W., Martek, I., Hosseini, M. R., Chen, C. (2019) "Political risk management of foreign direct investment in infrastructure projects: Bibliometric-qualitative analyses of research in developing countries", Engineering, Construction and Architectural Management.

https://doi.org/10.1108/ECAM-05-2019-0270

Kashiwagi, D. T. (1991) "Development of a Performance Based Design/Procurement System for Nonstructural Facility System", PhD Thesis, Arizona State University.

Kelley, J. E., Walker, M. R. (1959) "Critical-Path Planning and Scheduling", In: Proceedings of the Eastern Joint Computer Conference, Boston, MA, USA, pp. 160-173.

Kumar, S., Markscheffel, B. (2016) "Bonded-communities in HantaVirus research: a research collaboration network (RCN) analysis", Scientometrics, 109(1), pp. 533-550.

https://doi.org/10.1007/s11192-016-1942-1

Lawal, I. A., Klink, M., Ndungu, P., Moodley, B. (2019) "Brief bibliometric analysis of "ionic liquid" applications and its review as a substitute for common adsorbent modifier for the adsorption of organic pollutants", Environmental Research, 175, pp. 34-51.

https://doi.org/10.1016/j.envres.2019.05.005

Lechler, T. G., Yang, S. (2017) "Exploring the Role of Project Management in the Development of the Academic Agile Software Discourse: A Bibliometric Analysis", Project Management Journal, 48(1), pp. 3-18. https://doi.org/10.1177/875697281704800101

Lehtiranta, L. (2014) "Risk perceptions and approaches in multi-organizations: A research review 2000-2012", International Journal of Project Management, 32(4), pp. 640-653. https://doi.org/10.1016/j.ijproman.2013.09.002

LePatner, B. B., Jacobson, T. C., Wright, R. E. (2007) "Broken Buildings, Busted Budgets: How to Fix America's Trillion Dollar Construction Industry", University of Chicago Press, Chicago, IL, USA.

Lotka, A. J. (1926) "The frequency distribution of scientific productivity", Journal of the Washington Academy of Sciences, 16(12), pp. $317-323$.

Machado, F. J., Martens, C. D. P. (2015) "Project Management Success: A Bibliometric Analisys", Revista de Gestão e Projetos, 6(1), pp. $28-44$. https://doi.org/10.5585/gep.v6i1.310

Maia, J. L., Di Serio, L. C. (2017) "Uma Análise Bibliométrica Multifontes Sobre A Gerção de Valor ao Acionista e a Gestão de Projetos, Programas e Portfolios" (A Multi-Source Bibliometric Analysis about Shareholder Value Generation and Project, Portfolio and Program Management), Revista de Gestão e Projetos, 8(2), pp. 87-108. (in Portuguese) https://doi.org/10.5585/gep.v8i2.466

Md Khudzari, J., Kurian, J., Tartakovsky, B., Raghavan, G. S. V. (2018) "Bibliometric analysis of global research trends on microbial fuel cells using Scopus database", Biochemical Engineering Journal, 136, pp. 51-60. https://doi.org/10.1016/j.bej.2018.05.002

Merediz-Solà, I., Bariviera, A. F. (2019) "A bibliometric analysis of bitcoin scientific production", Research in International Business and Finance, 50, pp. 294-305. https://doi.org/10.1016/j.ribaf.2019.06.008 
Modak, N. M., Merigó, J. M., Weber, R., Manzor, F., de Dios Ortúzar, J. (2019) "Fifty years of Transportation Research journals: A bibliometric overview", Transportation Research Part A: Policy and Practice, 120, pp. 188-223. https://doi.org/10.1016/j.tra.2018.11.015

Molyneux, R. E. (1986) "Patterns, Processes of Growth, and the Projection of Library Size: A Critical Review of the Literature on Academic Library Growth", Library and Information Science Research, 8(1), pp. 5-28.

Ng, J. J., Chai, K. H. (2015) "A bibliometric analysis of Project Management research", In: 2015 IEEE International Conference on Industrial Engineering and Engineering Management (IEEM), Singapore, Singapore, pp. 976-980. https://doi.org/10.1109/IEEM.2015.7385794

Oliveira Lucena, J. P., da Costa Alves, T., de Medeiros Junior, J. V. (2019) "Governança de Projetos: uma análise bibliométrica de 2014 a 2018" (Project Governance: a bibliometric analysis of 2014 to 2018), Revista De Gestão e Projetos, 10(1), pp. 107-125. (in Portuguese) https://doi.org/10.5585/GeP.v10i1.10974

Office of Government Commerce (OGC) (2009) "Managing Successful

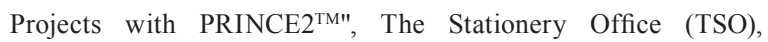
Norwich, UK.

Pauna, V. H., Buonocore, E., Renzi, M., Russo, G. F., Franzese, P. P. (2019) "The issue of microplastics in marine ecosystems: A bibliometric network analysis", Marine Pollution Bulletin, 149, Article Number: 110612 .

https://doi.org/10.1016/j.marpolbul.2019.110612

Peng, X., Che, W., Shou, Y. (2012) "A bibliometric description and content analysis of mega-project characteristics", In: 2012 IEEE International Conference on Industrial Engineering and Engineering Management, Hong Kong, China, pp. 2331-2336. https://doi.org/10.1109/IEEM.2012.6838164

Penha, R., de Camargo Guerrazzi, L. A., de Andrade, D. C. T., Cintra, R. F. (2017) "Produção Científica sobre Resource-Constrained Project Scheduling Problem: Um Estudo Bibliométrico e Bibliográfico" (Scientific Production about Resource-Constrained Project Scheduling Problem: A Bibliometric and Bibliographic Study), Revista de Gestão e Projetos, 8(2), pp. 71-86. (in Portuguese) https://doi.org/10.5585/gep.v8i2.488

Pricewaterhouse Coopers (PwC) (2009) "Need to know: Delivering capital project value in the downturn", PricewaterhouseCoopers (PwC), Industries: Energy, Utilities \& Mining, pp. 1-4. [online] Available at: https://www.pwc.com/co/es/energia-mineria-yservicios-publicos/assets/need-to-know-eum-capital-projects.pdf [Accessed: 01 November 2019]

Pritchard, A. (1969) "Statistical Bibliography or Bibliometrics?", Journal of Documentation, 25(4), pp. 348-349.

Project Management Institute (2017) "A guide to the project management body of knowledge", Project Management Institute, Newtown Square, PA, USA.

Rivera, A., Kashiwagi, D. (2016) "Creating a New Project Management Model through Research", Procedia Engineering, 145, pp. 1370-1377. https://doi.org/10.1016/j.proeng.2016.04.202

Rodrigues-Da-Silva, L. H., Crispim, J. A. (2014) "The Project Risk Management Process, a Preliminary Study", Procedia Technology, 16, pp. 943-949. https://doi.org/10.1016/j.protcy.2014.10.047
Rowlinson, S., Yunyanjia, A., Li, B., Chuanjingju, C. (2014) "Management of climatic heat stress risk in construction: A review of practices, methodologies, and future research", Accident Analysis \& Prevention, 66, pp. 187-198. https://doi.org/10.1016/j.aap.2013.08.011

Shi, G., Liu, N., Yu, X., Zhang, H., Li, S., Wu, S., Wang, W., Huang, P., Li, C. (2019) "Bibliometric Analysis of Medical Malpractice Literature in Legal Medicine from 1975 to 2018: Web of Science Review", Journal of Forensic and Legal Medicine, 66, pp. 167-183. https://doi.org/10.1016/j.jflm.2019.07.002

Silvius, G. (2017) "Sustainability as a new school of thought in project management", Journal of Cleaner Production, 166, pp. 1479-1493. https://doi.org/10.1016/j.jclepro.2017.08.121

Taroun, A. (2014) "Towards a better modelling and assessment of construction risk: Insights from a literature review", International Journal of Project Management, 32(1), pp. 101-115. https://doi.org/10.1016/j.ijproman.2013.03.004

Taroun, A., Yang, J. B., Lowe, D. (2011) "Construction Risk Modelling and Assessment: Insights from a Literature Review", The Built \& Human Environment Review, 4(1), pp. 87-97.

Uchitpe, M., Uddin, S., Lynn, C. (2016) "Predicting the Future of Project Management Research", Procedia - Social and Behavioral Sciences, 226, pp. 27-34. https://doi.org/10.1016/j.sbspro.2016.06.158

Utama, W. P., Chan, A. P. C., Zahoor, H., Gao, R. (2016) "Review of research trend in international construction projects: a bibliometric analysis", Construction Economics and Building, 16(2), pp. 71-82. https://doi.org/10.5130/AJCEB.v16i2.4866

van Eck, N. J., Waltman, L. (2010) "Software survey: VOSviewer, a computer program for bibliometric mapping", Scientometrics, 84(2), pp. 523-538. https://doi.org/10.1007/s11192-009-0146-3

Wang, M., Chai, L. (2018) "Three new bibliometric indicators/approaches derived from keyword analysis", Scientometrics, 116(2), pp. 721-750. https://doi.org/10.1007/s11192-018-2768-9

Weaver, P. (2007) "A brief history of project management: Is our profession 50 or 5000 years old?", APM, 19(11), pp. 1-4.

Yang, C., Wang, X., Tang, X., Wang, R., Bao, X. (2019) "Stem-Cell Research of Parkinson Disease: Bibliometric Analysis of Research Productivity from 1999 to 2018", World Neurosurgery. https://doi.org/10.1016/j.wneu.2019.10.087

Yıldız, T. (2019) "Examining The Concept of Industry 4.0 Studies Using Text Mining and Scientific Mapping Method", Procedia Computer Science, 158, pp. 498-507. https://doi.org/10.1016/j.procs.2019.09.081

Zamzami, N., Schiffauerova, A. (2017) "The impact of individual collaborative activities on knowledge creation and transmission", Scientometrics, 111(3), pp. 1385-1413. https://doi.org/10.1007/s11192-017-2350-X

Zhai, C., Ho, Y. S. (2018) "A Bibliometric Analysis of Distributed Control Publications", Measurement and Control, 51(3-4), pp. 113-121. https://doi.org/10.1177/0020294018768352

Zhang, J., Yu, Q., Zheng, F., Long, C., Lu, Z., Duan, Z. (2015) "Comparing keywords plus of WOS and author keywords: A case study of patient adherence research", Journal of the Association for Information Science and Technology (JASIST), 67(4), pp. 967-972. https://doi.org/10.1002/asi.23437 
Zhang, Y. C., Yang, W. (2018) "A Bibliometric Research on the Project Management Literatures", Aussino Acad Publ House, Marrickville, Australia.

Zhu, D., Wang, D., Hassan, S. U., Haddawy, P. (2013) "Small-world phenomenon of keywords network based on complex network", Scientometrics, 97(2), pp. 435-442.

https://doi.org/10.1007/s11192-013-1019-3
Zou, X., Vu, H. L. (2019) "Mapping the knowledge domain of road safety studies: A scientometric analysis", Accident Analysis \& Prevention, 132, Article Number: 105243.

https://doi.org/10.1016/j.aap.2019.07.019

Zou, X., Yue, W. L., Vu, H. L. (2018) "Visualization and analysis of mapping knowledge domain of road safety studies", Accident Analysis \& Prevention, 118, pp. 131-145.

https://doi.org/10.1016/j.aap.2018.06.010

\section{Appendix A}

Table 8 Top 30 keywords and the cluster of these keywords

\begin{tabular}{|c|c|c|c|c|c|c|c|c|}
\hline \multicolumn{3}{|c|}{ 1990-1999 } & \multicolumn{3}{|c|}{$2000-2009$} & \multicolumn{3}{|c|}{ 2010-2019 } \\
\hline Keyword & Cluster & Occurrences & Keyword & Cluster & Occurrences & Keyword & Cluster & Occurrences \\
\hline $\begin{array}{l}\text { Software project } \\
\text { management }\end{array}$ & 1 & 10 & Performance & 1 & 29 & Performance & 1 & 224 \\
\hline Information & 1 & 4 & Design & 1 & 15 & Construction & 1 & 90 \\
\hline Decision-making & 1 & 3 & Leadership & 1 & 13 & Knowledge & 1 & 82 \\
\hline Feedback & 1 & 3 & Implementation & 1 & 10 & Systems & 1 & 74 \\
\hline Systems & 1 & 3 & $\begin{array}{l}\text { Performance } \\
\text { evaluation }\end{array}$ & 1 & 10 & Leadership & 1 & 55 \\
\hline Environments & 1 & 2 & $\begin{array}{l}\text { Project management } \\
\text { office }\end{array}$ & 1 & 9 & Technology & 1 & 52 \\
\hline Perspective & 1 & 2 & Impact & 1 & 8 & Organizations & 1 & 50 \\
\hline Task-performance & 1 & 2 & Project performance & 1 & 8 & Implementation & 1 & 46 \\
\hline Design & 2 & 7 & Strategy & 1 & 8 & Communication & 1 & 36 \\
\hline Implementation & 2 & 5 & $\begin{array}{l}\text { Knowledge } \\
\text { management }\end{array}$ & 2 & 28 & Perspective & 1 & 36 \\
\hline Performance & 2 & 5 & Risk management & 2 & 27 & Model & 2 & 131 \\
\hline Communication & 2 & 4 & $\begin{array}{l}\text { Software project } \\
\text { management }\end{array}$ & 2 & 23 & Management & 2 & 85 \\
\hline Quality & 2 & 3 & Simulation & 2 & 18 & Design & 2 & 78 \\
\hline Teams & 2 & 3 & Systems & 2 & 16 & $\begin{array}{l}\text { Software project } \\
\text { management }\end{array}$ & 2 & 72 \\
\hline Technology & 2 & 3 & Optimization & 2 & 10 & Complexity & 2 & 59 \\
\hline Success & 2 & 2 & System dynamics & 2 & 9 & Uncertainty & 2 & 57 \\
\hline Software & 3 & 4 & Model & 3 & 23 & Risk management & 2 & 55 \\
\hline Case study & 3 & 3 & Construction & 3 & 21 & Product development & 2 & 45 \\
\hline Assessment & 3 & 2 & Success & 3 & 18 & PMBOK & 2 & 44 \\
\hline Evaluation & 3 & 2 & $\begin{array}{l}\text { Information } \\
\text { technology }\end{array}$ & 3 & 16 & Agile & 2 & 41 \\
\hline Microcomputer & 3 & 2 & Communication & 3 & 10 & Innovation & 3 & 105 \\
\hline Selection & 3 & 2 & Internet & 3 & 9 & Framework & 3 & 96 \\
\hline Innovation & 4 & 5 & Outsourcing & 3 & 9 & Project success & 3 & 53 \\
\hline Model & 4 & 4 & Uncertainty & 4 & 20 & Sustainability & 3 & 43 \\
\hline Strategy & 4 & 3 & Product development & 4 & 19 & Integration & 3 & 39 \\
\hline Adoption & 4 & 2 & Innovation & 4 & 17 & Success & 4 & 131 \\
\hline $\begin{array}{l}\text { Technological } \\
\text { discontinuities }\end{array}$ & 4 & 2 & Organizations & 4 & 12 & Impact & 4 & 93 \\
\hline Uncertainty & 4 & 2 & Quality & 5 & 17 & Strategy & 4 & 43 \\
\hline $\begin{array}{l}\text { Construction } \\
\text { management }\end{array}$ & 5 & 3 & Time & 5 & 11 & $\begin{array}{l}\text { Project management } \\
\text { office }\end{array}$ & 4 & 42 \\
\hline Information systems & 5 & 3 & Cost & 5 & 8 & $\begin{array}{l}\text { Portfolio } \\
\text { management }\end{array}$ & 4 & 36 \\
\hline
\end{tabular}




\section{Appendix B}

Table 9 Top 10 occurrences, degree, betweenness I indicator cluster coefficient

\begin{tabular}{|c|c|c|c|c|c|c|c|c|c|c|}
\hline \multirow[b]{2}{*}{ Row } & \multicolumn{2}{|c|}{ Top 10 occurrences } & \multicolumn{2}{|c|}{ Top 10 degree } & \multicolumn{2}{|c|}{ Top 10 betweenness } & \multicolumn{2}{|c|}{ Top 10 I indicator } & \multicolumn{2}{|c|}{$\begin{array}{c}\text { Top } 10 \text { clustering } \\
\text { coefficient }\end{array}$} \\
\hline & Keyword & 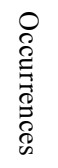 & Keyword & $\begin{array}{c}\underset{\varnothing}{8} \\
09 \\
0 \\
0 \\
0\end{array}$ & Keyword & 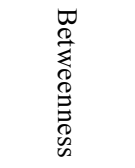 & Keyword & 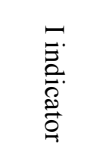 & Keyword & 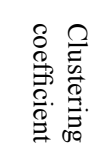 \\
\hline 1 & $\begin{array}{c}\text { Project } \\
\text { management }\end{array}$ & 185 & $\begin{array}{c}\text { Project } \\
\text { management }\end{array}$ & 626 & $\begin{array}{c}\text { Project } \\
\text { management }\end{array}$ & 397373.87 & $\begin{array}{l}\text { Human } \\
\text { resources }\end{array}$ & 731.6 & $\begin{array}{c}\text { Project } \\
\text { management }\end{array}$ & 0.007175 \\
\hline 2 & $\begin{array}{c}\text { Software } \\
\text { project } \\
\text { management }\end{array}$ & 15 & project & 49 & Leadership & 17439.83 & $\begin{array}{c}\text { Project } \\
\text { management } \\
\text { maturity } \\
\text { models }\end{array}$ & 687.25 & $\begin{array}{c}\text { Software } \\
\text { project } \\
\text { management }\end{array}$ & 0.076577 \\
\hline 3 & Project & 14 & $\begin{array}{l}\text { Project } \\
\text { success }\end{array}$ & 42 & Agile & 13332.72 & Simulation & 674.686 & $\begin{array}{l}\text { Project } \\
\text { success }\end{array}$ & 0.10641 \\
\hline 4 & $\begin{array}{l}\text { Project } \\
\text { success }\end{array}$ & 13 & $\begin{array}{c}\text { Software } \\
\text { project } \\
\text { management }\end{array}$ & 41 & $\begin{array}{l}\text { Project } \\
\text { success }\end{array}$ & 11506.86 & $\begin{array}{c}\text { Project } \\
\text { management }\end{array}$ & 634.782 & Project & 0.115152 \\
\hline 5 & $\begin{array}{l}\text { Knowledge } \\
\text { management }\end{array}$ & 10 & Management & 38 & Simulation & 11469.67 & $\begin{array}{c}\text { Business } \\
\text { model }\end{array}$ & 611.333 & $\begin{array}{l}\text { Knowledge } \\
\text { management }\end{array}$ & 0.131092 \\
\hline 6 & Management & 10 & $\begin{array}{l}\text { Knowledge } \\
\text { management }\end{array}$ & 37 & $\begin{array}{c}\text { Software } \\
\text { project } \\
\text { management }\end{array}$ & 10843.609 & $\begin{array}{c}\text { Construction } \\
\text { project } \\
\text { management }\end{array}$ & 592.247 & $\begin{array}{c}\text { Project } \\
\text { management } \\
\text { office }\end{array}$ & 0.13834 \\
\hline 7 & PMBOK & 9 & $\begin{array}{c}\text { Risk } \\
\text { management }\end{array}$ & 31 & Management & 9109.752 & Petri nets & 572.5 & PMBOK & 0.142292 \\
\hline 8 & Uncertainty & 8 & Agile & 31 & $\begin{array}{l}\text { Knowledge } \\
\text { management }\end{array}$ & 8464.573 & Leadership & 562.575 & Management & 0.153153 \\
\hline 9 & $\begin{array}{c}\text { Risk } \\
\text { management }\end{array}$ & 8 & Leadership & 31 & Sustainability & 8300.84 & e-learning & 550.8 & $\begin{array}{c}\text { Construction } \\
\text { project } \\
\text { management }\end{array}$ & 0.153846 \\
\hline 10 & Agile & 7 & Uncertainty & 29 & $\begin{array}{c}\text { Construction } \\
\text { project } \\
\text { management }\end{array}$ & 8291.464 & Life Cycle & 550.8 & Uncertainty & 0.172414 \\
\hline
\end{tabular}

